\title{
THE CONTRADICTIONS OF SPECIALIZATION: RHEUMATISM AND THE DECLINE OF THE SPA IN INTER-WAR BRITAIN
}

\author{
David Cantor
}

\begin{abstract}
Some twenty years ago I held an appointment at a large Poor Law Infirmary in London. I asked if I might be given charge of the rheumatic patients. The request was readily granted. I shall never forget the impression created by my first round of a long row of beds each occupied by a man crippled with arthritis. Some of them had been there for years unable to do so much as convey a drink or a bite to their mouths for themselves, to change their position in bed without being bodily lifted, or to perform any of the natural functions of the body without the attendance of the nursing staff on each and every occasion. ${ }^{1}$
\end{abstract}

Thus wrote Geoffrey Holmes, physician to the Harrogate Royal Bath Hospital in 1931. His was a common story. ${ }^{2}$ Spa physicians like Holmes, who were also interested in chronic rheumatism regularly pointed to the poor public provision for arthritis. They argued that sufferers languished in the Poor Law and Local Authority Infirmaries where low standards of treatment exacerbated their condition-a demoralizing realization for both nurse and physician. "I have no desire to make an emotional appeal", concluded Holmes after his moving account of his Poor Law experience, "but on humanitarian grounds alone no stone should be left unturned to save future sufferers from such a fate." 3 Yet who was to save sufferers from this fate? Certainly not the voluntary hospitals, for they rarely saw chronic arthritics. ${ }^{4}$ For Holmes, the "saviours" were to be the spas, and in particular their Mineral Water Hospitals, the only voluntary hospitals treating chronic rheumatic diseases. In 1926, the Bath physician Dr Kerr Pringle estimated that the seven mineral water hospitals in Britain saw about 8,600 patients a year, of which about 93 per cent would be

David Cantor, Ph.D., Wellcome Unit for the History of Medicine, Mathematics Tower, The University, Manchester M13 9PL.

\section{ACKNOWLEDGEMENTS}

I would like to thank Roger Cooter, Mary Fissell, and Philip Wood for commenting on earlier drafts of this paper. All errors, of course, remain my own.

1 'Royal Bath Hospital. Need for research work. Lord Harewood's forceful comments. Ignorance of arthritis', Harrogate Journal, 20 February 1931.

2 J. A. Glover, 'The need for an arthritis unit', (no date) received by MRC, 1 December 1924, Medical Research Council archives (hereafter MRC), 1325/2a.

${ }^{3}$ Op. cit., note 1 above.

${ }^{4}$ In 1928 the Ministry of Health estimated that chronic arthritis formed about 6.4 per cent of the in-patient work and less than $\mathbf{0 . 3}$ per cent of the out-patient work of the English Voluntary Hospitals. The Ministry also noted that the percentage was a little higher in the Royal Orthopaedic Hospital, where chronic arthritis was about 2.8 per cent of the in-patient and 4.5 per cent of the out-patient work. J. A. Glover, $A$ report on chronic arthritis, with special reference to the provision of treatment, London, HMSO, 1928. 
rheumatic. $^{5}$ To Holmes such figures fell far short of the numbers requiring hospitalization. Yet, he noted, "It should be borne in mind that whilst only a comparatively small proportion of the sufferers from rheumatism can be sent to the Spas either as hospital or private patients, for economic reasons, all benefit by any new knowledge acquired there.,"6

In looking back over the years, today's rheumatologists see the roots of their speciality in spa practice. ${ }^{7}$ While it is true that a number of important rheumatism units are now located in one-time mineral water hospitals, and while it is also true that a number of spa doctors turned themselves into rheumatologists when the NHS speciality was created in the 1940s, such backward glances do not capture the variety of (often contradictory) meanings of specialization in inter-war Britain, or the different paths which speciality development might have taken. The blame for ignoring the many meanings of specialization does not rest with medicine alone. Historians have been remarkably unwilling to see it as anything other than a medical phenomenon. According to Lindsay Granshaw, specialization in Britain was structured by institutional struggles between emergent specialist and established general physicians, rather than theoretical or technical factors. ${ }^{8}$ For Granshaw, as for Brian Abel-Smith, specialists were upwardly mobile, often marginal doctors who founded specialist dispensaries and hospitals (at least initially) as a way of circumventing blocked career ladders in the voluntary hospitals. ${ }^{9}$ Granshaw also understands the success of specialist hospitals in relation to patient demand and to the social kudos which philanthropists gained from supporting such institutions. But this is as far as she goes in separating out the interests of patrons and patients from those

${ }^{5}$ G. L. Kerr Pringle, 'Great Britain. II. The spas' in 'A discussion at a special meeting of the International Society of Medical Hydrology held jointly with the Section of Balneology and Climatology at the Royal Society of Medicine, London, November 27th, 1925', Archs med. Hydrol., 1926, 4: 121-30, on pp. $127-8$. Kerr Pringle provided the following estimates of the beds available at mineral water and hydropathic hospitals, and the numbers of patients treated annually.

Bath, Royal Mineral Water Hospital

Bath, Bellott's Hospital

Buxton, Devonshire Royal Hospital

Droitwich, St John's Brine Hospital

Harrogate, Royal Bath Hospital

Strathpeffer, Nicholson-Mackensie Hospital

Woodhall, Alexandra Hospital

At the hospitals at Llandrindod Wells and Leamington a certain

mineral water treatment. In addition there was the Hydropathic Hospital at Southport with eighty beds, where the average annual number of cases treated was about 715 . The Ministry of Health estimated that the major English spa hospitals had 665 beds between them, and that $\mathbf{4 0}$ per cent of the patients treated suffered from some form of chronic arthritis, perhaps some 6,000 a year: Glover, op. cit., note 4 above.

${ }^{6}$ Op. cit., note 1 above.

${ }^{7}$ G. D. Kersley, 'British rheumatology and rehabilitation', Hist. Med., 1974, 5(4): $10-14$.

${ }^{8}$ Lindsay Granshaw, "“Fame and fortune by means of bricks and mortar": the medical profession and specialist hospitals in Britain, 1800-1948', in Lindsay Granshaw and Roy Porter (eds.), The hospital in history, London and New York, Routledge, 1989, pp. 199-220; idem, St Mark's Hospital, London. A social history of a specialist hospital, London, King Edward's Hospital Fund for London, 1985.

9 Brian Abel-Smith, The hospitals 1880-1948. A study in social administration in England and Wales, London, Heinemann, 1964. 
of medicine. Generally, she sees specialization as a predominantly medical event, its meanings for philanthropists and for patients only secondary.

In another essay I have examined the reasons why donors gave to specialist rheumatism charities, and argued that often they had little to do with rheumatism itself. Rather, donors' reasons for giving were shaped by concerns about economic, social, and political disruption in the 1920s and 1930s, and charity and rheumatism became sites where such disruption could be resolved by cementing the bonds between higher and lower social groups. Further, such concerns shaped medical interest in rheumatism during the inter-war years. ${ }^{10}$ This paper has a more limited objective: outlining some of the many meanings of specialization for doctors, and arguing that they were structured by much more than the institutional and medical constraints outlined by Granshaw. Thus, while Holmes's comments about the neglect of rheumatism and the value of knowledge generated in the spas might have contributed to the emergence of rheumatology as a speciality within the NHS, ${ }^{11}$ his remarks also played on inter-war concerns about the economic and social costs of rheumatism: the drain such disorders imposed on industrial efficiency and on Approved Society funds. Holmes implied that specialization could contribute to the industrial recovery of Britain-much as Roger Cooter's orthopaedists claimed that fracture clinics would contribute to the revival of the British economy. ${ }^{12}$ In stemming British decline, specialization would, the argument ran, also help to unite capital and labour after the class conflict of the 1920s, turn the tide away from socialism, and (by the late 1930s) unite the nation against the Nazi threat. ${ }^{13}$

The rhetoric of national recovery aside, Holmes's statements also point to the significance of local issues to the process of speciality formation-in this case, the fluctuating fortunes of the spas. J. A. R. Pimlott has suggested that the spas underwent a revival in the 1930s because they "called the science of medical hydrology to their assistance". ${ }^{14}$ But few others would accord medical hydrology such power. Most see a long-term decline in the popularity of spas after they burst upon the scene as the first leisure resorts in Britain as part of the commercial revolution of the eighteenth century. ${ }^{15}$ In the nineteenth century, competition from the seaside and foreign resorts contributed to their decline, ${ }^{16}$ and, in contrast to

\footnotetext{
10 'The aches of industry: philanthropy and rheumatism in inter-war Britain', in J. Barry and Colin Jones (eds.), Medicine and charity in Western Europe before the Welfare State, London, Routledge, (forthcoming).

ii It might also be argued that Holmes's comments contributed specifically to the formation of the modern rheumatology unit at the Royal Bath Hospital, Harrogate, and its academic counterpart in Leeds University, the Rheumatism Research Unit. See my forthcoming book on the history of arthritis and rheumatism charities in twentieth-century Britain, provisionally entitled These rheumatic isles. A social history of British rheumatism charities, 1920-1986.

12 Roger Cooter, (provisional title) Surgery and society in peace and war: the making of modern orthopaedics, 1880-1945, forthcoming.

13 Cantor, op. cit., note 11 above.

14 J. A. R. Pimlott, The Englishman's holiday. A social history, London, Faber \& Faber, 1947, p. 256.

15 R. S. Neale, Bath 1680-1850. A social history, London, Boston, and Henley, Routledge, 1981; J. H. Plumb, 'The commercialization of leisure', in N. McKendrick, John Brewer, and J. H. Plumb, The birth of $a$ consumer society. The commercialization of eighteenth-century England, London, Hutchinson, 1983.

${ }^{16}$ On the seaside resorts see J. Walton, The English seaside resort. A social history, 1750-1914, Leicester University Press and New York, St Martin's Press, 1983. On Victorian and Edwardian foreign travel see John Pemble, The Mediterranean passion. Victorians and Edwardians in the south, Oxford University Press, 1987. See also J. Walvin, Leisure and society, 1830-1950, London and New York, Longman, 1978.
} 


\section{David Cantor}

Pimlott, Bernard Jennings has seen no sign of a recovery in 1930s Harrogate. ${ }^{17}$ Instead, he describes a slow decline in lay and medical faith in spa treatment, hastened by the economic difficulties of the late 1920s and early 1930s. This decline stimulated a number of local efforts to revive and diversify the town's economy, efforts which also perhaps influenced Holmes's comments about the neglect of rheumatism. If, as Holmes suggested, Harrogate's Bath Hospital were to gain a reputation as a national centre for the treatment of rheumatism, perhaps more visitors would be attracted to the town in search of relief. Thus, Holmes's appeal aligned spa doctors with hoteliers, shopkeepers, and other local businessmen in the common effort to revive the local economy after the 1929 slump.

But specializing in rheumatism was not the only way to attract support. For many spa doctors specializing in disease impinged on another tradition within the spas that saw medical hydrologists as specialists in technique. In this view, the spa doctor was competent to deal not just with one, but with the many varieties of disorders sent to the spa. His specialist knowledge was of the spa and its waters-much in the way that a general surgeon treated a variety of disorders using surgery. Thus the physician at, say, Bath would be a specialist in the use of Bath's waters (and any accessory techniques such as diet, massage, rest, and so on), Harrogate doctors would specialize in the waters of that town, Buxton doctors in Buxton's waters and so on. Such views blurred the distinction between generalist and specialist; after all, was someone who specialized in technique and generalized in disease a specialist or a generalist? From this perspective, the medical hydrologists' skills were geographically specific and, consequently, their interests were closely tied to the town in which they worked and to its economic fortunes.

THE PROBLEMS OF DECLINE I: 1914-1929

To physicians in the 1920 s it was the First World War that seemed the major turning point in the economic fortunes of the spas. There was an influx of between 50,000 and 75,000 wounded and invalided soldiers into the spas. ${ }^{18}$ But most significantly, the war provided a temporary respite from foreign competition. Observers perceived the revival of the British commercial spirit amidst the isolation of war. "Nowhere has British enterprise been more evident during the past twelve months", noted the Prescriber in 1916, "than at the various spas and health resorts of these islands ... they have not failed to seize the opportunity offered them at this time". ${ }^{19}$ By 1918, an over-optimistic British Medical Journal noted that the pre-war habit of the well-to-do of taking the cure abroad had been broken. ${ }^{20}$

By 1920/1, however, the war-time hope that British resorts had cracked the Continental grip on spa-going had begun to fade. The lifting of travel restrictions to the Continent in 1918 had revived old complaints about the harm foreign competition

${ }^{17}$ Bernard Jennings (ed.), A history of Harrogate and Knaresborough, Huddersfield, The Advertiser Press, 1970.

${ }^{18} \mathrm{~W}$. Edgecombe, 'The treatment of wounded and invalided soldiers by waters and baths-IV. Great Britain', Archs med. Hydrol., 1924, no. 4: 140-3.

19 'British spas and their waters', Prescriber, 1916, 10: 57.

20 'British spas', Br. med. J., 1918, ii: 385. 
did to the resorts. 21 "The years of respite from foreign competition have gone by," lamented one commentator, "and even in the summer of 1920 the effects of the reopening of Western Europe to visitors from our shores began to be felt". ${ }^{22}$ As Britain slipped into recession after the short-lived post-war economic boom, commentators noted that high prices and social and industrial unrest aided foreign competitors. ${ }^{23}$ Spa authorities were forced to postpone schemes to up-grade facilities, and the delay ushered in a period of gloom in the spas. By 1924, unfavourable exchange rates aided foreign resorts. ${ }^{24}$

As foreign competition began to bite, the major spa authorities banded together in 1921 to form the British Spa Federation (BSF), and doctors launched the International Society of Medical Hydrology. Membership of the BSF was limited to the principal spas in Britain and the Empire, ${ }^{25}$ and the organization aimed to provide "a certain standard of efficiency in treatment"; "a guarantee as regards standard". 26 In this objective it had much in common with other businesses that aimed to combat the revival of foreign competition after World War I by federation and rationalization, standardization, and improved efficiency. ${ }^{27}$ The rules of the BSF excluded resorts which did not meet certain standards of hotel accommodation, amenities, and bathing facilities, and, consequently, enabled it to criticize the poor standards available in some continental resorts. "I have in mind particularly one Continental Spa I recently visited," noted the secretary of the Federation, F. J. C. Broome, 28 "which for dirty and dilapidated conditions would indeed be difficult to beat, and yet this Spa is one of the best known and most fashionable in the world." While the reader was left to ponder which of the many fashionable Continental resorts he might be referring to, Broome attacked the quality of staff they employed-"the contrast between the intelligence and consequent ability of the British Spa attendant and the peasant class from which the foreign Spa is largely recruited is most marked."29 Science was brought to the aid of the BSF. British spas, he claimed, were "not one whit behind the Continent"30 in the scientific administration of treatments. Yet none of this was sufficient. Even though the BSF reduced the tariff at all its spas in 1922, doctors still complained that it was cheaper to visit a French or Swiss resort from London, than to go to one in Scotland. To these physicians, rail fares seemed far too high, and in combination with the costs of hotel accommodation they ensured that all but the very rich and very poor (who could

21 'Visits to foreign health resorts', ibid., p. 324.

22 Neville Wood, 'British spas and their waters. A foreword', Prescriber, 1921, 15: 113-19, on p. 113.

${ }^{23} \mathrm{Idem}$, 'British spas and their waters. A foreword', ibid., 1922, 16: 97-102.

24 C. W. Buckley, 'Spa treatment in the British Isles. A foreword', ibid., 1924, 18: 99-103.

25 In 1922 these comprised Bath, Buxton, Cheltenham, Droitwich, Harrogate, Leamington, Llandrindod Wells, Woodhall and all the New Zealand spas. F. J. C. Broome, 'The British Spas Federation', ibid., 1922, 16: 103-5.

26 Ibid., p. 103.

${ }^{27}$ Leslie Hannah, The rise of the corporate economy, 2nd ed., London and New York, Methuen, 1983, chapter 3.

${ }^{28}$ Broome, op. cit., note 25 above, p. 104. For a similar comment about the poor sanitary conditions of Continental spas see Buckley, op. cit., note 24 above, p. 100.

29 Broome, op. cit., note 25 above, p. 104.

30 Ibid. 


\section{David Cantor}

obtain free treatment in the mineral water hospitals) were barred from such resorts. ${ }^{31}$

Where spa authorities combined into a "business" association, spa doctors followed with their own organization. In December 1921 leading spa doctors and physical therapists who used hydrological techniques launched an International Society of Medical Hydrology (ISMH), as part of a wider attempt to isolate Germany scientifically and commercially after World War I. ${ }^{32}$ The Society when it was founded had 101 members-over 63 per cent came from France and Britain-and there were no German members despite the fact that Germany had been one of the principal destinations of pre-war spa goers. ${ }^{33}$ Britons dominated the organization. The first president, R. Fortescue Fox, as well as the treasurer and honorary secretary, were British. In 1922 it launched its own journal, the Archives of Medical Hydrology, under dual French-British editorial control. To the British editor of the Archives, Charles Buckley, the ISMH aimed to gain for medical hydrology "wider recognition as an important branch of medicine possessing a thoroughly scientific basis", 34 but with Germany excluded from the ISMH, science served to unite the war-time allies, and isolate Germany.

Ironically, science also served as a weapon in commercial competition between the erstwhile war-time allies. The British in particular saw the ISMH as an opportunity to catch up with the French commercial competition. Thus in 1923 a Joint Committee of the ISMH and the Balneological and Climatological Section of the Royal Society of Medicine (RSM) approached the Ministry of Health, arguing that if the latter recognized medical hydrology and encouraged teaching in the subject and scientifc analysis of the waters, Britain would more easily meet French competition. One million invalids a year, it pointed out, were referred to the chief European resorts. One French resort alone saw 10,900 British visitors, who spent $£ 300,000 .{ }^{35}$ The implication was clear. Improve the status of medical hydrology, and more people would be tempted to visit the home resorts.

Obviously, the British had to be politic about their commercial aspirations when speaking through the ISMH. In such circumstances the link between commerce and science receded, and, instead, the British portrayed the spas' attempts to gain

\footnotetext{
31 'Cheaper spas', Br. med. J., 1922, i: 533. R. Fortescue Fox, 'Cheaper spas', ibid., pp. 542-3.

32 On similar splits in radiology and physics see D. Serwer, The rise of radiation protection: science, medicine and technology in society, 1896-1935, B.N.L. 22279, Informal Report, Brookhaven National Laboratory, December 1976; and P. Forman, 'Scientific internationalism and the Weimar physicists: the ideology and its manipulation in Germany after World War I', Isis, 1973, 64: 151-80, and J. Kevles, 'Into hostile political camps: the re-organisation of international science in World War I', ibid., 1970, 62: 47-60. For an in-house history of the ISMH see M. Messini, History of the International Society of Medical Hydrology and Climatology (1922-1966), Pisa, Nistri-Lischi, 1966.

${ }^{33}$ For the membership list of the ISMH when it was formed see 'International Society of Medical Hydrology', Archs med. Hydrol., 1922, no. 1: 44. The figures do not refer to honorary members, of which there were a further 13 ( 5 from France and 4 from England). The only representative of the central powers was Austria, with 4 members and 1 honorary member.

${ }^{34} \mathrm{C}$. W. Buckley, 'The study of medical hydrology. Formation of an international society', Prescriber, 1922, 16: $105-6$, on p. 106.

${ }^{35} \mathrm{~W}$. Edgecombe and R. Fortescue Fox, 'Statement for the Ministry of Health from the Joint Committee (of the International Society of Medical Hydrology and the Section of Balneology of the Royal Society of Medicine) to promote the teaching of medical hydrology in England', November 1923, Public Record Office, Kew (hereafter PRO), MH58/159.
} 
scientific status as an apolitical venture which merely served to bring British resorts up to the standard of those abroad. For example, in his preface to the first number of the Archives, Clifford Allbutt never once mentioned the commercial opportunities opened up by improving resorts. Instead, he described science in British resorts in almost transcendental terms; the creation of "laboratories of a much higher craft", 36 in which patients no longer saw the "cure" as amusement but as "a wholly serious undertaking", ${ }^{37}$ and where amusement itself now had a "'psychological' justification". 38 Meanwhile, he suggested, a small body of "able, far-sighted, scientific workers" 39 were waiting in the wings to bring British hydrological practice up the scientific standards of the Continent. The fact that this claim was somewhat at odds with the suggestion of the BSF that British hydrological practice was already scientifically comparable to continental practice went unremarked.

Medical hydrologists also saw science as important in controlling the commercial aspirations of local authorities and spa owners. They felt that the development of spas on purely commercial lines led authorities to exaggerate the properties of the waters, ${ }^{40}$ and it was for this reason that they collaborated with the BSF in an effort to reduce what they saw as over-enthusiastic advertising. Indeed, the BSF seemed keen to oblige. Its rules of membership admitted spas to the Federation only if their waters had been assessed for therapeutic value; if the town had medical men who specialized in spa practice; and if the resort agreed to give treatment (with certain minor exceptions) only on the authority of a physician. Despite such rules medical hydrologists continued to worry about the ways in which spas tried to compete with foreign resorts. Some doctors, for example, resisted suggestions that British resorts could open on Sundays, arguing that commercial rather than medical interests inspired this proposal. If commercial interests won, then the doctors believed that "week-enders" would flock to the spas. A town which saw such an influx, they argued, would be spoiled, "bringing it down to the level of a holiday resort". ${ }^{41}$ Others complained about the amusements provided at spas. In 1923 Charles Buckley felt uneasy about the extent to which British resorts emulated the "modern craze for pleasure and artificial amusements", ${ }^{42}$ lavishing vast sums on palatial hotels, theatres, and ballrooms. It seemed that the essential medical status of the resort was threatened. Buckley compared the "modern craze" unfavourably to the way a department store attracted customers, but at the same time wrote that the spas (as medical resorts) would never make money and, playing on debates about municipal capitalism, further argued that ratepayers might become disillusioned with paying out vast sums for such little return. ${ }^{43}$

${ }^{36}$ Clifford Allbutt, 'Preface', Archs med. Hydrol., 1922, no. 1: 1-3, on p. 1.

37 Ibid.

38 Ibid.

39 Ibid.

40 'The development of our spas', Prescriber, 1925, 19: 89-90.

41 'British spas and foreign competition', ibid., 1922, 16: 107-8, on p. 108.

${ }^{42}$ C. W. Buckley, 'British spas and their waters. A foreword', ibid., 1923, 17: 95-9, on p. 95.

${ }^{43}$ Ibid. Richard Roberts, 'The corporation as impresario: the municipal provision of entertainment in Victorian and Edwardian Bournemouth', in John K. Walton and James Walvin (eds.), Leisure in Britain 1780-1939, Manchester University Press, 1983. For a discussion of how doctors perceived commercialization see David Cantor, 'Cortisone and the politics of drama', in John Pickstone (ed.), Medical innovation in historical context, (forthcoming). 


\section{David Cantor}

THE PROBLEMS OF DECLINE II: 1929-1939

In 1929 the spas were again hit by the onset of the Depression. Numbers visiting the resorts fell, ${ }^{44}$ though hopes of a revival followed Britain's departure from the Gold Standard in 1931. After this the pound fell against the currencies of Britain's major trading rivals and those of the Continental countries where many spa-goers took the cure. English travellers abroad found that foreign banks refused to exchange sterling, and the papers were full of accounts of stranded Britons selling their jewels for the fare home, or of the lieutenant-commander who had to leave his golf clubs and a cigarette case as security for a loan to telegraph to England. ${ }^{45}$ Whatever the truth of such tales, they point to a widespread concern about the cost of holidaying abroad. The Prince of Wales, speaking at the annual meeting of the Travel Association, captured the fear. "I want our friends in foreign countries", he stated, "to realise that this dissuasion from travelling abroad for purely pleasure reasons is only due to the present financial situation." 46

Businessmen were quick to point out that Britain generally ignored the huge potential income from tourism. The retailer Gordon Selfridge, for example, noted that France estimated her revenue from tourists in a normal year to be about $£ 100,000,000$. In contrast Britain saw a paltry $£ 15,000,000 .{ }^{47} \mathrm{He}$ argued for greater state and local authority support for tourism, and his plea was supported by other businessmen ${ }^{48}$ who felt that the potential for growth seemed enormous. The public was encouraged to "See Beautiful Britain". 49

Doctors also saw the crisis as an opportunity to attract visitors back to the spas. Echoing the Prince of Wales's comments the year before, the editor of the Prescriber urged doctors to refer their patients to home resorts:

In these days of national financial depression it is recognized that the duty of every citizen is not so much to save money as to spend it wisely which in the present circumstances means spending it so that it will remain in the country. With all the goodwill in the world to our friends across the Channel, we must delay sending them our money until happier times arrive. ${ }^{50}$

By then some doctors were suggesting that the BSF's support for science had become somewhat discredited. They felt that some spa authorities were not serious about the medical side of the work, and that they cared little "so long as a stream of

\footnotetext{
44 In 1932, Bath Corporation's Spa Committee outlined the effects of the Depression on the spa. Starting from what it termed a "good" year-1928 - the committee showed that total receipts for the spring season fell 18 per cent with a fall of 10 per cent in the number of medical treatments (not including the swimming baths) given between 1928 and 1932. The fall in numbers was especially damaging because the committee had reduced costs by about 10 per cent. Bath City Record Office (hereafter BCRO), 'Report of the Bath Spas Committee', April to June 1932, Bath Spa Committee Minute Book No. 10. For the effect of the 1929 slump on Harrogate see Jennings, op. cit., note 17 above, chapter 15.

45 'Stranded Britons selling jewels on Continent', News Chronicle, 23 September 1931.

46 'Travel and trade', Daily Mail (Continental Edition), 25 December 1931.

${ }^{47}$ H. Gordon Selfridge, 'Tourists in England. An invisible export', The Times, 18 September 1931.

48 O. S. Meiklejohn, 'Tourists in England', ibid., 25 September 1931.

49 ' $£ 100,000,000$ from tourists', Bristol Times and Mirror, 23 September 1931.

50 The Editor, 'Spa treatment in the British Isles', Prescriber, 1932, 26: 77-8, on p. 77. For further comments on the Prince's speech see 'The Prince's speech' Br. J. physical Med., 1932, 7: 1-2.
} 
visitors of one sort or another is attracted to their locality" ${ }^{51}$ Much the same was said of other health resorts, such as those at the seaside. Indeed, the British Journal of Physical Medicine complained that the local authorities at other resorts cared even less for scientific medicine that those at the spas. Competition was so strong between them that the Journal despaired of ever getting them to collaborate. ${ }^{52}$

Nevertheless, in 1931 doctors joined with resort authorities to found a "Wintering in England Movement", which was renamed the British Health Resorts Association the following year. The President of the BMA, W. G. Willoughby, argued that this Association should capitalize on the recent fall in the pound, though he saw the poor reputation of the British climate as a potential drawback. ${ }^{53}$ For this reason, the British Health Resorts Association issued a memorandum lauding the "Winter Warmth" of British seaside resorts, and claiming that they compared favourably with Alpine and Riviera resorts. ${ }^{54}$ The claim did not persuade all doctors, ${ }^{55}$ but it signified a renewed attempt to bring medical science to the aid of commerce.

The spas received special mention in a memorandum produced by the Association in 1932, in which they were distinguished from Continental ones by the "invigorating and tonic" quality of their climate. ${ }^{56}$ At the same time the editor of the Prescriber also highlighted the poor reputation of the British climate amongst doctors. His solution was to concede that only the weather was poor. The English climate was, he wrote, "the finest in the world, it is our weather that is bad-occasionally." 57 An article accompanying this editorial explained that climate differed from weather essentially because it was measured over a longer period of time. ${ }^{58}$ None could have failed to note the national urgency of distinguishing climate from weather. This was the same editorial that echoed the Prince of Wales in asking doctors not to send their patients abroad.

But had questions of national or commercial needs subverted medical judgement? Some doctors felt that this was the case. Whereas in December 1932 the Harrogate physician Geoffrey Holmes had asked spa goers to "'Buy British' and get the value for money as well as have the satisfaction of being patriotic by doing so", 59 in June 1934 the British Journal of Physical Medicine (BJPM) was warning against such calls. ${ }^{60}$ By now, it claimed, the two to three years of freedom from Continental competition were over: economic recovery at home, it argued, was principally to blame, but so too was the fact that many Continental countries-notably Hungary and Czechoslovakia - had cut rail and hotel charges and had resumed advertising in the English press. Nevertheless, there was "no longer any question of over-riding

\footnotetext{
51 'Spas and health resorts', ibid., 1931, 6: 83-4, on p. 84.

52 Ibid.

53 W. G. Willoughby in 'Wintering in England. Claims of the home resorts', Br. med. J., 1931, ii: 1150-2.

54 'Memorandum on British winter seaside resorts', ibid., pp. 1151-2.

55 A. A. Warden, 'Wintering abroad', ibid., p. 923.

56 'The British spas. A medical appreciation', ibid., 1932, i: 1095.

57 'Spa treatment', op. cit., note 50 above, p. 78.

${ }^{58}$ K. R. Collis Hallowes, 'Climate as a factor in spa treatment', Prescriber, 1932, 26: 79-84.

59 G. Holmes, 'British and foreign spas', Br. med. J., 1932, ii: 1125-6, on p. 1126.

60 'Spas and health resorts', Br. J. physical med., 1934, 9: 21-2.
} 


\section{David Cantor}

judgement by consideration of national policy",61 and the BJPM suggested that medicine should never have succumbed to such calls in the first place. The Prince of Wales, quoted in favour of nationalism in 1931, now was cited as an advocate of travel abroad. The editorial concluded,

Obviously we cannot expect to thrive in medical matters on a policy which, if followed to its inevitable end, would result in nations and peoples maintaining an insular disregard of all progress and all knowledge outside their own borders. ${ }^{62}$

Nationalism and custom, it argued, should never again sully medical judgement on the respective merits of British and foreign spas and resorts. By 1937, the Prescriber had also begun to acknowledge that science recognized no flags or frontiers. Now it argued that British spas offered all the treatments available abroad, as well as a range of climates and environments to suit all conditions. The appeal had shifted from naked commerce to science, from nationalism to internationalism. Any nationalism remaining was far more muted. Some argued that because British spas offered facilities comparable to those on the Continent, Britons had no need to undergo the fatigue of a long Channel crossing or rail journey. ${ }^{63}$ Others continued to argue that the English could winter in England more comfortably than abroad ${ }^{64}$ Still others cashed in on the "Holidays-with-Pay" movement of the $1930 \mathrm{~s},{ }^{65}$ and on the renewed interest in physical fitness. ${ }^{66}$

\section{THE MEANINGS OF SPECIALIZATION}

Spa doctors thus faced a range of conflicting expectations and demands in the inter-war period. Tensions between nationalism and internationalism, and between science and commerce, structured their responses to the shifting economic fortunes of the spas, and also ultimately, their attempts to define themselves as medical hydrologists. However, this was a time when the ways in which specialization would fit into the medical landscape was being fiercely debated, and consquently what was meant by medical hydrology was often unclear. For some, specialization meant little more than accreditation in medical hydrology; for others it meant social hydrology (bordering on specializing in rheumatism); while for others it became incorporated into the emerging speciality of physical medicine. But each option was problematic, and many doctors wavered between all of them. The same polarities of local/national, commercial/medical, technique/disease characterized all options. Indeed, these conflicts illustrate the plasticity of the very concept of a speciality in this era.

\section{Specialization and Nationalism}

Just as nationalist sentiments shaped much of the early 1920 s interest in reviving

${ }^{61}$ Ibid., p. 21.

62 Ibid., p. 22.

${ }^{63}$ The Editor, 'Our British spas', Prescriber, 1937, 31: 73-85.

64 'Bournemouth as a winter resort', Br. J. physical Med., 1937, 11: 224.

65 'British Health Resorts Association. Conference at Skegness', ibid., 1937, 12: 10.

66 'British Health Resorts Association. Convention at Bath', ibid., p. 174. See also G. R. P. Aldred Brown, 'The spa as a national asset in the maintenance of physical fitness', Prescriber, 1938, 32: 63-6. 
the declining fortunes of the spas, so they also shaped interest in specialization. Fortescue Fox, for example, argued to the Ministry of Health in 1923 that the major reason why the English went abroad was that Britain trained no specialists. ${ }^{67}$ This point was supported by the Harrogate physician Wilfred Edgecombe, who wrote that what distinguished the British spas from those on the Continent was the fact that most spa doctors were not specialists in medical hydrology, but were engaged as well in general and semi-consulting practice. To Edgecombe this was partly due to the fact that most English resorts were open throughout the year, so that English spa doctors had less leisure and opportunity for research work than those in other countries, who could study and take up research out of season. The problem was also one of a lack of governmental enthusiasm for medical hydrology. English spas were under municipal or private control, rather than that of the state; no cure-tax was levied, and no governmental funds were available. ${ }^{68}$

Surveys conducted by hydrologists confirmed that, compared to other countries, British medical hydrology was poorly organized. ${ }^{69}$ There were no special or systematic courses of instruction in medical hydrology in any of the British universities or medical schools; and no laboratories set apart for experimental research in it and ancillary subjects. As a result, medical hydrologists felt that most practitioners did not think of hydrology as a part of a therapeutic armamentarium, and had little incentive to specialize. So too, the term "specialist" easily blurred into what Fortescue Fox called an "accredited spa practitioner".70

The term specialist also signified a hierarchical structure within medicine. A 1923 leader in the Archives of Medical Hydrology depicted a three-fold hierarchy comprising general practitioners (who should have a working knowledge of the principles of medical hydrology), practising hydrologists (who were, or ought to have been, specialists), and experts (research workers and teachers). ${ }^{71}$ As Edgecombe wrote the same year, in the article summarized above, it was men (and perhaps women) in the middle and upper ranks who would bring back the tourists and, as Holmes would suggest (see the beginning of this chapter), acquire the knowledge that would benefit many beyond the spas. It was for this reason that the Joint Committee approached the newly-formed Ministry of Health in 1923, as the economy dug its way deeper into recession, suggesting that the Ministry's sanction for specialists might be the solution to the drift back to the Continent. They were to be disappointed, for the Ministry declined to recognize medical hydrology. ${ }^{72}$ Subsequently, the neglect of the subject remained a subject of repeated comment throughout the inter-war years despite the fact that the 1923 Joint Committee of the ISMH and the Balneological and Climatological Section of the Royal Society of Medicine organized a course of lectures on medical hydrology given at London University and a study tour at

${ }^{67}$ R. Fortescue Fox to G. Newman, 30 November 1923, PRO:MH58/159.

68 W. Edgecombe in 'The teaching of medical hydrology', Archs med. Hydrol., 1923, no. 3: 104-5.

69 'The present state of medical hydrology in the countries represented [in the International Society of Medical Hydrology]', ibid., 1922, no. 1: 8-12.

${ }^{70}$ R. Fortescue Fox, 'A foreword', Prescriber, 1920, 14: 99-104, on p. 104.

71 'The teaching of medical hydrology', Archs med. Hydrol., 1923, no. 3: 99-100.

72 PRO:MH58/159. 


\section{David Cantor}

Harrogate, ${ }^{73}$ and the institution of a lectureship (the first and only) in Leeds in 1938, to which the Harrogate physician, Geoffrey Holmes, was appointed. ${ }^{74}$

\section{Rheumatism and Social Hydrology}

Following the failure of their approach to the Ministry, medical hydrologists changed tack. Now they argued that specialization would not only encourage the commercial revival of the spas, but also increase industrial efficiency through the more effective treatment of rheumatic sufferers. Rheumatism had been highlighted as a major drain on industrial efficiency and on the insurance industry in the Ministry of Health's 1924 report on the incidence of rheumatic diseases in England and Wales. This report claimed that between one-sixth and one-seventh of all benefits were paid out for rheumatic diseases, at a cost of about $£ 1,800,000$ a year. In addition, industry lost about 3,141,000 weeks of work annually from the insured population alone. ${ }^{75}$ As a consequence, Fortescue Fox, the BSF, and the United Patriots Approved Society argued to the Royal Commission on the National Health Insurance in July 1925 that spa treatment should be available as a statutory benefit to which every insured person should have a right. To the relief of Ministry officials who opposed the suggestion, the Commission did not adopt this proposal. Nevertheless, it (and an alternative suggestion that spa treatment should be available as an additional benefit) were kept alive throughout the 1920s, the subject of repeated appeals to the Ministry from medical hydrologists, trades unions, approved societies, and the BSF. ${ }^{76}$

By the end of the 1920s, these and similar attempts abroad to extend spa treatment to insured workers prompted some medical hydrologists to redefine their speciality as "social hydrology". 77 In Britain-though not everywhere-the term was linked principally to concerns about the industrial and financial costs of rheumatism, an association that seemed to bring medical hydrology close to disease specialization, a prospect that was anathema to some hydrologists. ${ }^{78}$ Medical hydrologists had been at the forefront of the interest in rheumatism. A British Committee on Rheumatism had been founded in 1926, as a sub-committee of the ISMH. The Committee included not only spa doctors but also medical hydrologists who worked in or advocated the creation of physical treatment clinics for rheumatism in major urban and industrial areas. Conflict between clinic and spa factions led the Committee to break away from the ISMH in 1928, arguing that the study of rheumatism could not be limited to medical hydrology. ${ }^{79}$ As such "social hydrology" not only bordered very closely to

\footnotetext{
${ }^{73}$ The course was held from 29 May to 2 June 1923, and details can be found in PRO:MH58/159.

74 'Medical hydrology', Prescriber, 1938, 32: 61-2.

${ }^{75}$ Ministry of Health, Reports on public health and medical subjects, No 23. The incidence of rheumatic diseases, London, HMSO, 1924.

${ }_{76}$ For details of these appeals see Cantor, op. cit., note 11 above.

77 'Social hydrology', Archs med. Hydrol., 1930, 8: 368. R. Fortescue Fox in “"Social hydrology”' (A public service)', ibid., 1931, 9: 413-15.

${ }^{78}$ See the Editor's note in W. S. C. Copeman, 'A historical sketch of the development of social hydrology in England', ibid., 1930, 8: 293-5. A. P. Cawadias, 'The health resort physician', ibid., 1932, 10: 98-9.

79 Dawson of Penn, Thomas Horder, W. H. Willcox, W. Hale White, Andrew Balfour, Leonard Hill and R. Fortescue Fox, to J. A. Glover, 26 October 1928, PRO:MH55/60.
} 


\section{Rheumatism and the decline of the spa}

disease specialization, but also consigned it to a sub-speciality within a broader field of "rheumatology".

\section{Technique and Disease Specializations}

At the time the Joint Committee approached the Ministry, most medical hydrologists probably saw "specialization" as meaning specialization in technique. Thus when in 1923 Fortescue Fox argued that the health resort physician was a specialist who devoted himself to incipient and chronic maladies (to the exclusion of acute illnesses), and to the application of physical remedies to their relief, a 1925 editorial in the Prescriber argued that a new order of specialists was arisingspecialists not in disease, but in remedies. ${ }^{80}$ It is of course possible to read Fortescue Fox's statement as an argument for specializing in incipient and chronic maladies as well as technique, and indeed even those who attacked disease specialization far more vehemently than Fortescue Fox seem to have recognized that at least a minimal knowledge of disease was necessary. Thus in 1932 one opponent of disease specialization, A. P. Cawadias, commented that the health resort physician's "knowledge of these morbid conditions [rheumatism and respiratory diseases] which he is called upon to treat must be very great, but his real speciality consists in the particular waters or baths or climatic factors of his resort." 81

This conflict over the "real" speciality of a medical hydrologist was present in most discussions of techniques and disease specialization in 1920s and 30s. Inevitably, when someone proposed specializing in technique, it raised questions about the technical specialists' skill in dealing with the disease they treated. One solution would have been for technical specialists to accept an ancillary place within medicine. But, as Larkin has noted, practitioners of physical techniques (including medical hydrologists) felt that this accorded them only a secondary status within medicine and increasingly fought against such a position. ${ }^{82}$ Instead, medical hydrologists played on the old prejudice in internal medicine against specialization, arguing that they were in fact generalists who only specialized in technique, an argument that had the double effect of both countering criticisms of their skills in treating diseases, and the suggestion that they be ancillary to general physicians, or specialists in diseases.

Fortescue Fox himself worried that specialization might undermine what he called the "unity of medicine", 83 and in the early 1920 s the omens must have seemed favourable for a new technique-based speciality of medical hydrology. Techniquebased specialization had been boosted by the creation of the British Association for the Advancement of Radiology and Physiotherapy in 1917, and by the creation of a Diploma of Radiology at Cambridge in 1920. Though medical hydrologists were not sure whether they wanted a diploma themselves ${ }^{84}$ for Fortescue Fox "the use of external treatment and of waters, like that of drugs, will in the future be a matter for

\footnotetext{
${ }^{80}$ R. Fortescue Fox, 'The breakdown of middle life', Lancet, 1923, i: 55-7; 'The development of our spas', Prescriber, 1925, 19: 89-90.

81 Cawadias, op. cit., note 78 above, p. 98

${ }^{82}$ G. Larkin, Occupational monopoly and modern medicine, London and New York, Tavistock, 1983, chapter 4.

${ }_{83}^{83}$ Fox, op. cit., note 80 above, p. 57.

${ }^{84}$ Op. cit., note 71 above. R. Fortescue Fox, 'The teaching of medical physics with special reference to medical hydrology', Archs med. Hydrol., 1931, 9: 382-4.
} 


\section{David Cantor}

special knowledge and careful prescription." 85 Such specialist knowledge would bring the spa-goer seeking serious medical attention back to the home resorts, and at the same time counter the commercial tendencies among spa authorities, enabling them to develop as national health centres.

Fortescue Fox supported his argument for technical specialization by drawing an analogy between the use of waters and the use of drugs and vaccines. He argued that one of the reasons why the administration of waters, like drugs, required special knowledge was because, also like drugs, they had a specific chemical or pharmacological action - "No one doubts the remedial value of drugs and vaccines, even in minimal doses. Why then should not the natural solutions of salts and metals and gases and ferments have an equally powerful effect?"86 There remained the slight problem of proof. Even Fortescue Fox had to admit that the action of the waters was imperfectly understood. But the clinician's special knowledge served as a buttress against any scientific doubters of spa treatment. Echoing the distrust of applied science and the approval of craft skills and rule-of-thumb experience that Lawrence has identified within the rhetoric of twentieth-century British physicians, ${ }^{87}$ Fortescue Fox (and others) argued that until science came up with evidence (which it surely would) one would have to rely on the experience of spa practitioners. ${ }^{88}$

Specialization, as far as it meant special knowledge of the use of the waters, thus formed an important defence of the spas as health resorts. Elsewhere, Fortescue Fox attacked those who thought that people went to the spas simply "for a change of scene, rest, exercise, beautiful country, wholesome diet, recreation, and possibly also a change of air." 89 Yes, he argued, these were important, but they formed only an adjunct to the waters, on which the medical hydrologist was the only expert. Adopting a sanitary analogy, he argued that just as waters could be carriers of disease, they could also be carriers of health. Indeed, for Fortescue Fox, as we were made up predominantly of water, by taking the waters "we return to ourselves, to what is related to us, to things with which we have a singular agreement, and which therefore on a priori grounds should be capable of playing a part in the changes and exchanges that take place in our tissues." 90 Conversely, if we eliminated water as a method of treatment we also eliminated "the chief medium of the energies and of the mineral materials of which our liquid and solid tissues continually stand in need." 91

Not all medical hydrologists were convinced of the specific action of the waters. Fortescue Fox himself seems to have only accorded it a limited role in the treatment of disease, and argued equally for a humoral model of treatment, claiming in 1920

\footnotetext{
${ }^{85}$ Idem, 'National health centres: A foreword', Prescriber, 1926, 20: 91-3, on pp. 92-3.

${ }^{86}$ Idem, 'A foreword', ibid., 1920, 14: 99-104, on p. 101.

${ }^{87}$ C. Lawrence, 'Incommunicable knowledge: science, technology and the clinical art in Britain, 1850-1914', J. contemp. Hist., 1985, 20: 503-20.

${ }^{88}$ R. Fortescue Fox, 'Spa treatment in the British isles. A foreword', Prescriber, 1925, 19: 109-13. For another example of this reasoning, C. W. Buckley, 'British spas and their waters. A foreword', ibid., 1923, 17: $95-9$.

${ }^{89}$ Fox, op. cit., note 88 above, p. 109 . See also idem, op. cit., note 86 above.

90 Idem, op. cit., note 86 above, p. 110.

91 Ibid.
} 


\section{Rheumatism and the decline of the spa}

that "It is the rationale of the health resort to bring disorder into adjustment" ${ }^{92}$ Such views gained strength throughout the 1920 s as it seemed that interest in rheumatism might turn medical hydrology itself into a disease speciality. They were expressed most consciously in a conference in 1928 which aimed to revive the humoral model under the title of neo-humoralism. ${ }^{93}$ Humoralism focused attention on the sick person and his or her environment, and away from anatomic-pathological conceptions of disease that focused on organs and cells. Disease could not, in the neo-humoralist's view, be so reduced- "there were no diseases of organs, of cells, or of tissues. Disease was a disharmony of life, a defect of adaptation",94 and it implied very different forms of treatment to orthodox medicine. As Cawadias put it,

If, for example, we consider chronic rheumatism as a lesion of the joints, there is no other treatment than surgical interference; if we consider it as an effect of a microbian action, we can intervene only with antiseptics, serums, vaccines or by extirpation of infective foci. But the case is very different if we consider this disease as the result of a defective reaction of the neuro-endocrino-humoral integrative mechanism, towards a constellation of environmental conditions, a defective reaction which causes certain specific disturbances in general metabolism, whose ultimate results are the lesions of the joints. ${ }^{95}$

Then, according to Cawadias, it would be possible to re-establish the normal response of this "integrating mechanism".

Such views drew on the new physiology of the late nineteenth century ${ }^{96}$ and also shaped the idea of specialism, reinforcing the tendency towards specializing in technique, and at the same time questioning the subdivision of internal medicine into rheumatology, neurology, cardiology, and so on. As Matthew Ray put it "The tendency, too prevalent in recent years, towards a narrow specialism is the negation of wholeness or the conception of the unity of the body." 97 For Cawadias, internal medicine could not be divided up, for specialization in diagnosis was impossible, and diagnosis was the most important part of internal medicine-treatment was itself a diagnosis. Instead of concentrating on one part of the body, the diagnostician had to look at everything, and Cawadias argued that only a speciality which looked at all diseases-along the lines of the continental speciality of internal diseases-was feasible. This left narrow specialization to more manual practices such as surgery, where repeated practice of a particular technique might lead to improvements in skill. To Cawadias, medical hydrology was precisely this type of manual technique. Thus,

92 Idem, op. cit., note 86 above, p. 100

93 'The humoral factor in disease (Neo-Hippocratism)', Archs med. Hydrol., 1929, 7: 143-53. See also M. B. Ray, 'Concepts of disease', ibid., 1927, 5: 227-8; 'The new humoral pathology', ibid., 1928, 6: 66.

94 A. P. Cawadias in 'International Society of Medical Hydrology. Annual meeting in England', Br. med. J., 1928, ii: $716-18$, on p. 717.

${ }^{95}$ A. P. Cawadias, 'The Neo-Hippocratic theory as a basis of medical thought and practice', Archs med. Hydrol., 1929, 7: 148-51, on p. 150.

${ }_{96}$ G. Geison, Michael Foster and the Cambridge School of physiology. The scientific enterprise in late Victorian society, Princeton University Press, 1975. J. Harley Warner, The therapeutic perspective. Medical practice, knowledge, and identity in America, 1820-1885, Cambridge, Mass., and London, Harvard University Press, 1986.

97 Ray, op. cit., note 93 above, p. 228. 


\section{David Cantor}

after a 1930s editorial in the Archives of Medical Hydrology seemed to him to propose that health resort physicians should specialize in diseases, Cawadias argued that the health resort physician could only be a specialist in technique. ${ }^{98}$

Such views were clearly important to a profession seeking to persuade working people to take their holidays in the spas, to recuperate from the stress and strain of modern living. The emphasis on the sick-man was also important to a profession used to dealing with the rich, who might not be so amenable to the prodding and poking that the poor received. ${ }^{99}$ Nonetheless, opposition to specializing in disease did not itself go unopposed. One physician at the Royal Brine Baths Clinic for Rheumatism at Droitwich, J. Patterson, feared that the spas were losing their lead in the battle against rheumatism, and argued,

If we are honest we must admit that we ourselves are largely responsible for the situation and have hitherto avoided the larger issue. We have been content to be "specialists" in one particular treatment instead of equipping ourselves as specialists in the particular disease from which the patient is suffering. ${ }^{100}$

Patterson saw a great need for more research into rheumatism, and specialization in the disease as a means of ensuring that research was carried out in the spas-views entirely unreconcilable with those of Cawadias. But both played on similar concerns. Both wanted to encourage the revival of the spas after the Slump, but whereas Cawadias saw it as impossible for the spa physician to compete with his London counterpart, Patterson was happy to try. Whereas Cawadias saw disease specialization as threatening the unity of internal medicine, Patterson saw it as essential if the spas were to retain their lead in the treatment of disease.

\section{Medical Hydrology and Physical Medicine}

The whole debate was further complicated by attempts to bring the different aspects of physical medicine together. Hitherto, physical medicine had been little more than a loose collection of techniques-actinotherapy, balneology, electrical treatment, and so on, a rag-bag of therapies which became associated under the rubric "physical medicine". Two factors promoted this uneasy association. First was the continuing perception by physical practitioners that organized medicine remained skeptical about the therapeutic benefits of such remedies. ${ }^{101}$ But this continued unease was heightened by the challenge and competition from lay physiotherapists in the second and third decades of the twentieth century. ${ }^{102}$ By the late 1920 s and early

\footnotetext{
${ }^{98}$ Cawadias, op. cit., note 78 above. Partial support for this position came from Fortescue Fox, 'Centres of convalescence. The advantages of therapeutic specialisation', Archs med. Hydrol., 1932, 10: 73-7.

99 N. D. Jewson, 'The disappearance of the sick-man from medical cosmology 1770-1870', Sociology, 1976, 10: 225-44.

$100 \mathrm{~J}$. W. T. Patterson, 'The British spas and the problem of rheumatism-the need for organisation and authority', Archs med. Hydrol., 1932, 10: 100.

101 "It is surprising that simple drugs should be so extensively prescribed for use in the home, whilst simple physical methods are rarely advocated by the medical man, although they are often of great service. The modern doctor is, I think, 'rather afeared of old wives' remedies,' in case his reputation for Science should suffer": W. S. C. Copeman, The treatment of rheumatism in general practice, London, Edward Arnold, 1933, p. 113.

${ }^{102}$ Larkin, op. cit., note 82 above, chapter 4.
} 
1930s, when concern about disease specialization was at a height, so too was physical medicine closing ranks. The British Journal of Actinotherapy was renamed the British Journal of Actinotherapy and Physiotherapy in 1929, and broadened its scope from light and ray treatments to include hydrotherapy. In 1932 it became the British Journal of Physical Medicine, the year after the Balneological and Climatological Section of the RSM became the Physical Medicine Section.

Spa practitioners felt very uneasy about this association, fearing that it would lead to the subsumption of spa practice under medical hydrology. One response to the emergence of physical medicine was to argue that medical hydrology was the "kernel of Physical Medicine", ${ }^{103}$ but unsurprisingly this did not go down well with the other specialities in the field. But this argument did not deal with spa practitioners' unease about being lumped together with hydrological practices elsewhere. After all, if medical hydrology could be obtained at a physical treatment centre, why go to the expense of going to a spa? As a consequence, as Cawadias suggested, spa practitioners argued that their special knowledge was of particular waters or baths or climatic factors, what the Archives of Medical Hydrology called the "Therapeutics of Place". 104

Another response was to shift the emphasis from technique specialization to disease specialization, as Patterson at Droitwich suggested, if the "war" against rheumatism was not to pass to the urban and industrial physical treatment clinics. For Patterson and for other physicians hoping to play on the growing interest in rheumatic diseases, competition from the burgeoning physical treatment centres, such as the Red Cross's rheumatism clinic at Peto Place, London, could only be met by specializing in diseases. This clinic had by now achieved significant support from the Approved Societies, and unlike the spa clinics, had been recognized by the Ministry of Health as approved centres for the treatment of rheumatism under the Additional Benefits scheme of the NHI. The Ministry still refused to countenance the extension of the additional benefits scheme to the spas, and men like Patterson probably hoped this would change if the spas specialized further in disease. Others may have agreed, hoping too that the reputation of the spa as a treatment centre for rheumatism would also attract others to the resort. Holmes's appeal for rheumatism, noted at the start of this chapter, relied on the generosity of local Harrogate doctors, who constituted almost 30 per cent of the donors to his appeal by $1935 .{ }^{105}$

\section{CONCLUSION}

This chapter has examined the ways in which economic, commercial, scientific, and professional factors influenced conceptions of specialization. It has shown that the economic fortunes of the spas can be divided into two periods during the 1920s and 1930s, marked by crises in foreign competition, and that arguments for specialization played on these crises, but in mutually opposed ways. Specialization itself had a very blurred meaning. At some times it appeared to mean little more than an accredited spa practitioner, while at other times it referred to specialization in technique or

103 'Q.E.D.', Archs med. Hydrol., 1932, 10: 61.

104 'The therapeutics of place', ibid., 1927, 5: 290.

${ }^{105}$ Cantor, op. cit., note 11 above. Jennings, op. cit., note 17 above. 


\section{David Cantor}

disease. Sometimes specialization blurred into generalism, sometimes not. This flexibility of meaning seems to have been important to medical hydrologists. It enabled them to play on various (and sometimes competing) loyalties and associations. Sometimes it argued for nationalism, sometimes internationalism. Sometimes it argued for commercial benefits, sometimes it eschewed them. Such tensions were highlighted by historical contingencies such as the departure from the Gold Standard, war, rising unemployment, escalating costs to the national health insurance scheme- even the rainy British weather. In a world where it was as yet unclear what a specialist should be, these contingencies shaped the options available to would-be specialists, and even the concept of a speciality itself. 